\title{
HAMBATAN PASIEN PENYAKIT JANTUNG KORONER (PJK) UNTUK MENJALANI REHABILITASI JANTUNG
}

\author{
Nurul Fatimah Saripudin ${ }^{1}$, Etika Emaliyawati ${ }^{1}$, Irman Somantri ${ }^{1}$ \\ ${ }^{1}$ Fakultas Keperawatan Universitas Padjadjaran \\ nurulfatimahh@gmail.com
}

\begin{abstract}
Abstrak
Tingkat kepatuhan dan partisipasi pasien Penyakit Jantung Koroner (PJK) jantung pasca revaskularisasi dalam menjalani rehabilitasi jantung masih sangat rendah yang dipengaruhi oleh berbagai hambatan. Hal ini dapat menyebabkan terjadinya kekambuhan penyakit serta menurunkan kualitas hidup pasien. Penelitian ini bertujuan untuk mengetahui hambatandari pasien PJK dalam menjalani rehabilitasi jantung di Poliklinik Jantung RSUP Dr. Hasan Sadikin Bandung. Metoda penelitian menggunakan deskriptif kuantitatif dengan sampel sebanyak 42 responden yang menggunakan accidental sampling selama 1 bulan. Instrumen penelitian menggunakan kuisioner Cardiac Rehabilitation Barrier Scale dari Grace et.al tahun 2011 yang telah diterjemahkan. Analisa data menggunakan distribusi frekuensi dan rerata skor. Hasil penelitian diperoleh bahwa hambatan berdasarkan aspek logistik menjadi hambatan dengan rata-rata skor (mean) tertinggi yaitu 2,29. Selanjutnya adalah hambatan berdasarkan aspek waktu dengan rerata skor 2,24, kemudian berdasarkan aspek pelayanan kesehatan dengan rerata skor 2,19 dan yang paling rendah memperoleh rerata skor adalah berdasarkan status fungsional pasien yaitu 2,14. Jarak dan ketidaktahuan pasien mengenai rehabilitasi jantung menjadi dua hambatan yang memiliki rerata skor tertinggi yaitu 2,52 dan 2,38. Hambatan berdasarkan aspek logistik yaitu jarak menjadi hambatan yang paling banyak terjadi. Maka dari itu, peneliti menyarankan untuk dapat menerapkan rehabilitasi jantung dengan setting rumah yang disesuaikan dengan karakteristik pasien.
\end{abstract}

Kata Kunci: Hambatan, PJK, Rehabilitasi Jantung

\begin{abstract}
Barrier Of Coronary Artery Disease (Cad)Patient Who Undergoing Cardiac Rehabilitation At Cardiac Clinicrsup Dr. Hasan Sadikin Bandungthe. The level of adherence and participation of patients coronary artery disease $(C A D)$ post revascularization who undergoing cardiac rehabilitation was still very low which is influenced by various barriers. This may lead a recurrence of disease and decrease of the quality of life. This research aims to know about barrier of CAD patient who undergoing cardiac rehabilitation in Cardiac Clinic RSUP Dr. Hasan Sadikin Bandung. This research used a descriptive quantitative method and involved 42 respondent were taken by accidental sampling technique which held in a month. The research instrument used Cardiac Rehabilitation Barrier Scale from Grace et.al in 2011 that has been translated into Indonesian. Analysis of data used distribution of frequencies and mean score. The results obtained that the barrier based on logistic aspect with mean 2.29 become highest mean score. Then the barriers based on aspect of time with mean value score 2.24 , then based on the aspect of health care with mean score 2.19 and the lowest mean score is based on the patient's functional status 2.14. Distance and patient's ignorance about cardiac rehabilitation came in two barriersand the highest mean value was 2.52 and 2.38. The barriers based on the logistic aspect was distance, the most happened in cardiac rehabilitation. Researchers suggested that for apply the home based cardiac rehabilitation with adjusted of characteristic patient.
\end{abstract}

Keyword: Barriers, CAD, cardiac rehabilitation

\section{Pendahuluan}

Riset Kesehatan Dasar (Riskesdas) tahun 2013 menyatakan bahwa berdasarkan diagnosis dokter prevalensi Penyakit Jantung Koroner (PJK)di Indonesia sebesar $0,5 \%$ atau diperkirakan sekitar 883.447 orang sedangkan berdasarkan diagnosis dokter dan atau tanda gejalanya sebesar $1,5 \%$ atau diperkirakan sekitar 2.650 .340 orang.World Health Organization (WHO) pun menyatakan bahwa $60 \%$ dari seluruh penyebab kematian penyakit jantung 
adalah penyakit jantung koroner (Depkes RI, 2006).

Pengobatan secara medis PJK saat ini secara umum dilakukan dengan terapi farmakologi dan revaskularisasi jantung (Majid, 2007). Tindakan revaskularisasi yang telah terbukti baik pada PJK yang disebabkan oleh aterosklerotik adalah tindakan pembedahan CABG (Coronary Artery Bypass Graft) dan tindakan PCI (Percutaneous CoronaryIntervention). Pasien -pasien PJK yang sudah menjalani tindakan revaskularisasi jantung akan menjalani tindakan selanjutnya yaitu rehabilitasi jantung.

Rehabilitasi jantung adalah program profesional yang tersupervisi untuk membantu pasien dalam proses penyembuhan dari serangan jantung, pembedahan jantung, tindakan PCI seperti stenting dan angioplastyyang terdiri dari pelayanan edukasi dan konseling untuk membantu pasien PJK dalam meningkatkan aktivitas fisik, menurunkan tanda gejala, meningkatkan kesehatan dan menurukan resiko terjadinya serangan jantung kembali (AHA, 2015).

Pelaksanaan mengenai program rehabilitasi jantung dilakukan sejak pasien masih dalam perawatan di rumah sakit (inpatient) hingga keluar dari rumah sakit (outpatient) (Radi, Joesoef, \& Kusmana, 2009). Hal tersebut terbagi menjadi 4 fase yaitu fase I saat masih dalam perawatan di rumah sakit dan fase II, III, IV bagi pasien yang sudah keluar dari rumah sakit. Program-program yang dilakukan saat rehabilitasi jantung itu diantaranya latihan aktivitas fisik, konseling diet atau nutrisi dan manajemen berat badan (Massimo Francesco, 2010).

Rehabilitasi jantung memiliki banyak manffat yang dirasakan oleh pasien. Penelitian Nurlaeci (2015) memperoleh hasil bahwa terdapat pengaruh yang signifikan dari latihan progresif fase I rehabilitasi jantung terhadap tekanan darah dan denyut nadi (heart rate) pada pasien sindrom koroner akut. Selain itu, manfaat dari rehabilitasi jantung adalah meningkatkan kualitas hidup pasien dengan mengurangi terjadinya tanda gejala, menurunkan angka kematian yaitu $2,2 \%$ untuk yang menjalani rehabilitasi jantung sedangkan 5,3\% untuk yang tidak menjalaninya (Mampuya, 2012) dan dapat meningkatkan kualitas hidup pasine (Hastuti, 2014).

Upaya pelayanan fasilitas rehabilitasi jantung di Indonesia sudah cukup baik salah satunya berada di Rumah Sakit Hasan Sadikin (RSHS) Bandung. Namun saat ini, tingkat kepatuhan dan pasrtisipasi pasien dalam menjalani rehabilitasi jantung masih sangat rendah. Tiksnadi (2015) telah memperoleh data bahwa hanya 11,35\% pasien PJK yang menjalani rehabilitasi jantung di RSHS Bandung. Rendahnya tingkat kepatuhan serta partisipasi pasien dalam rehabilitasi jantung ini terjadi juga di negara lain. Dominic (2005) menemukan bahwa di Hongkong hanya $25 \%$ pasien yang datang hingga sesi terakhir ketika menjalani rehabilitasi jantung. Hal tersebut dipengaruhi oleh berbagai hambatan.

$$
\text { Sophie O'Connell }
$$

menyatakan bahwa ada beberapa hambatan yang memengaruhi kedatangan para pasien dalam rehabilitasi jantung, yaitu : waktu pelaksanaan, informasi yang diberikan kepada pasien oleh tenaga kesehatan, usia dan jenis kelamin, status ekonomi, komunikasi, faktor kebiasaan dan faktor psikologis. Dunlay (2009) pun menyebutkan bahwa faktor psikososial menjadi faktor yang paling berpengaruh terhadap kedatangan pasien melakukan rehabilitasi jantung, kemudian alasan selanjutnya adalah perasaan mengenai pentingnya rehabilitasi, faktor pendidikan kesehatan dan kemampuan mengemudi. Selain itu, Lee (2011) juga mengidentifikasi beberapa alasan utama pasien tidak melaksanakan program rehabilitasi jantung, yaitu: hambatan fisik (kurangnya transportasi dan jarak yang terlalu jauh dari pusat rehabilitasi jantung, dan biaya rehabilitasi yang tinggi), hambatan personal (malu berpartisipasi, 
rendahnya pengetahuan mengenai tujuan program) dan kurangnya rekomendasi dari tim kesehatan.

Penelitian atau survey mengenai hambatan sudah banyak dilakukan di luar negeri dan belum pernah ada dilakukan di Indonesia. Karakteristik geografis Indonesia yang cukup berbeda dengan luar negeri seperti wilayah Indonesia yang cukup luas tetapi dengan kondisi jalan raya yang masih banyak dalam perbaikan, angkutan umum yang masih belum mencukupi, pelayanan rehabilitasi jantung yang hanya ada di rumah sakit besar seperti RSHS serta tenaga medis yang memiliki keahlian dalam rehabilitasi jantung masih sangat sedikit sehingga akan menjadi salah satu hambatan. Oleh karena itu, diperlukan penelitian lebih lanjut mengenai hambatan - hambatan apa saja yang terjadi di Indonesia terutama di Bandung yanng terdapat RSHS sebagai salah satu penyedia pelayanan rehabilitasi jantung.

Tingginya jumlah pasien PJK saat ini seharusnya berbanding lurus dengan tingkat partisipasi saat menjalani rehabilitasi jantung. Namun, saat ini tingkat kepatuhan dan partisipasi pasien PJK pasca rawat untuk mengikuti rehabilitasi jantung masih rendah dikarenakan berbagai hambatan. Oleh karena itu, menjadi penting untuk mengetahui hambatan-hambatan apa saja yang terjadi pada pasien PJK pasca rawat dalam menjalani rehabilitasi jantung

\section{Metode}

Metode penelitian ini menggunakan deskriptif kuantitatif yang bertujuan untuk mengetahui hambatan dari Penyakit Jantung Koroner (PJK) untuk Menjalani Rehabilitasi Jantung. Variabel penelitian ini adalahhambatan dalam menjalani rehabilitasi jantung pasien PenyakitJantung Koroner (PJK) dengan 4 sub variabel yaitu aspek pelayanan kesehatan, aspek logistik, aspek waktudan status fungsional pasien. Populasi dalam penelitian ini adalah semua pasien Penyakit Jantung Koroner (PJK) yang menjalani rawat jalan di Poliklinik Jantung RSUP Dr. Hasan Sadikin. Sampel yang diperoleh sebanyak 42 responden dengan teknik pengambilan sampling yaitu accidental sampling selama 1 bulan sejak April hingga Mei 2016. Instrumen yang digunakan dalam penelitian ini adalah kuisioner Cardiac Rehabilitation Barriers Scaleyang di buat oleh Grace et al., pada tahun 2011. Instrumen penelitian yang digunakan telah di alih bahasakan ke bahasa Indonesia oleh ahli bahasa serta telah dilakukan content validityserta face validity. Analisa data menggunakan nilai rata-rata skor (mean). Setiap sub variabel diperoleh nilai mean masing-masing. Kemudian untuk variabel utama dianalisa berdasarkan dari rata-rata skor (mean) dari setiap variabel yang diurutkan dari mean skor paling tinggi hingga paling rendah.

\section{Hasil Penelitian}

Karakteristik responden pada penelitian ini adalah Pasien Penyakit Jantung Koroner di Poliklinik Jantung RSUP Dr. Hasan Sadikin Bandung selama penelitian ditampilkan dalam tabel 1.

Berdasarkan tabel 1 dari 42 responden diperoleh bahwa usia responden yang paling banyak adalah usia 56-65 tahun sebanyak 20 responden $(47,6 \%)$ dengan jenis kelamin laki-laki sebanyak 30 responden $(71,4 \%)$. Tingkat pendidikan responden paling banyak adalah Diploma atau lebih tinggi sebanyak 22 responden $(52,4 \%)$, serta sebanyak 25 responden $(49,5 \%)$ masih bekerja.

Hasil karakteristik lain pun diperoleh pula jarak tempat tinggal menuju RSHS paling banyak $<25 \mathrm{~km}$ yaitu sebanyak 24 responden $(57,1 \%)$ dengan status perkawinan kawin sebanyak 40 responden (95,2\%). Para responden pun telah melakukan lama pengobatan paling banyak selama $>1$ tahun sebanyak 22 responden $(57,2 \%)$, kemudian riwayat pengobatan responden paling banyak adalah yang menjalani medikasi dan telah pasang ring (PCI) yaitu sebanyak 21 responden $(50,0 \%)$. 
Tabel 1.

Distribusi Frekuensi Karakteristik Responden $(n=42)$

\begin{tabular}{|c|c|c|c|}
\hline No & Karakteristik & $\mathrm{f}$ & $\%$ \\
\hline & Usia & & \\
\hline 1. & $35-45$ tahun & 1 & 2,4 \\
\hline 2. & $46-55$ tahun & 10 & 23,8 \\
\hline 3. & $56-65$ tahun & 20 & 47,6 \\
\hline \multirow[t]{2}{*}{4.} & $>65$ Tahun & 11 & 26,2 \\
\hline & Jenis Kelamin & & \\
\hline 1 & Laki-Laki & 30 & 71,4 \\
\hline \multirow[t]{2}{*}{2} & Perempuan & 12 & 28,6 \\
\hline & Tingkat Pendidikan & & \\
\hline 1. & SD & 6 & 14,3 \\
\hline 2. & SMP & 5 & 11,9 \\
\hline 3. & SMA & 9 & 21,4 \\
\hline \multirow[t]{2}{*}{4.} & Diploma atau lebih tinggi & 22 & 52,4 \\
\hline & Jarak menuju RSHS & & \\
\hline 1. & $<25 \mathrm{~km}$ & 24 & 57,1 \\
\hline 2. & $25-50 \mathrm{~km}$ & 4 & 9,5 \\
\hline 3. & $50-75 \mathrm{~km}$ & 0 & 0,00 \\
\hline 4. & $75-100 \mathrm{~km}$ & 0 & 0,00 \\
\hline \multirow[t]{2}{*}{5.} & $>100 \mathrm{~km}$ & 14 & 33,3 \\
\hline & Pekerjaan & & \\
\hline 1. & Bekerja & 25 & 49,5 \\
\hline \multirow[t]{2}{*}{2.} & Tidak Bekerja & 17 & 40,5 \\
\hline & Status Perkawinan & & \\
\hline 1. & Kawin & 40 & 95,2 \\
\hline \multirow[t]{2}{*}{2.} & Janda/Duda & 2 & 4,8 \\
\hline & Lama Pengobatan & & \\
\hline 1. & $0-5$ bulan & 9 & 16,7 \\
\hline 2. & 6 bulan -1 tahun & 11 & 26,2 \\
\hline \multirow[t]{2}{*}{3.} & $>1$ tahun & 22 & 57,2 \\
\hline & Riwayat Pengobatan & & \\
\hline 1. & Medikasi dan Pasang Ring (PCI) & 21 & 50,0 \\
\hline 2. & Medikasi & 13 & 31,0 \\
\hline \multirow[t]{2}{*}{3.} & Medikasi dan Coronary Artery Bypass Graft (CABG) & 8 & 19,0 \\
\hline & Keikutsertaan dalam Rehabilitasi Jantung & & \\
\hline 1. & Tidak Pernah & 24 & 57,1 \\
\hline 2. & Rutin & 16 & 38,1 \\
\hline \multirow[t]{2}{*}{3.} & Kadang-kadang & 2 & 4,8 \\
\hline & Pertemuan Ke- dalam Rehabilitasi Jantung & & \\
\hline 1. & Pertemuan ke-1 & 3 & 16,7 \\
\hline 2. & Pertemuan ke-2 & 1 & 5,6 \\
\hline 3. & Pertemuan ke-5 & 3 & 16,7 \\
\hline 4. & Pertemuan ke-6 & 1 & 5,6 \\
\hline 5. & Pertemuan ke-7 & 1 & 5,6 \\
\hline 6. & Pertemuan ke-9 & 3 & 16,7 \\
\hline 7. & Pertemuan ke-12 & 6 & 33,3 \\
\hline
\end{tabular}

Gambaran hambatan pasien PJK dalam menjalani rehabilitasi jantung dianalisa menggunakan nilai rata-rata skor (mean). Setiap sub variabel diperoleh nilai mean masing-masing. Kemudian untuk variabel utama dianalisa berdasarkan dari rata-rata skor (mean) dari setiap variabel yang diurutkan dari mean skor paling tinggi hingga paling rendah. 
Tabel 2.

Rata-rata skor (mean) dan standar deviasi dari setiap sub variabel Hambatan pasien Penyakit Jantung Koroner (PJK) dalam menjalani Rehabilitasi Jantung $(\mathrm{n}=42)$

\begin{tabular}{|c|c|c|c|c|c|c|}
\hline No & Sub Variabel & $\begin{array}{l}\text { Min - Max } \\
\text { Teoritis }\end{array}$ & Nilai Tengah & Min- Max & Mean & SD \\
\hline 1. & Aspek logistik & $1-4$ & \multirow{2}{*}{$\begin{array}{l}2,5 \\
2,5\end{array}$} & $2,14-2,52$ & 2,29 & 0,16 \\
\hline 2. & Aspek waktu & $1-4$ & & $2,19-2,29$ & 2,24 & 0,05 \\
\hline 3. & $\begin{array}{l}\text { Aspek } \\
\text { kesehatan }\end{array}$ & $1-4$ & 2,5 & $2,12-2,38$ & 2,19 & 0,09 \\
\hline 4. & Status Fungsional & $1-4$ & 2,5 & $2,12-2,17$ & 2,14 & 0,02 \\
\hline & $\begin{array}{l}\text { Berdasarkan tabel } \\
\text { Na setelah diurutkan } \\
\text { gi maka rata - rata } \\
\text { jalani rehabilitasi jan } \\
\text { ak terjadi adalah pa } \\
\text { zan nilai mean } 2,29 \mathrm{dc} \\
0,16 \text {, selanjutnya } \\
\text { asarkan aspek waktı }\end{array}$ & $\begin{array}{l}\text { liperoleh data } \\
\text { i yang paling } \\
\text { mbatan dalam } \\
\text { g yang paling } \\
\text { aspek logistik } \\
\text { tandar deviasi } \\
\text { tuk hambatan } \\
\text { iperoleh rata- }\end{array}$ & \multicolumn{4}{|c|}{$\begin{array}{l}\text { rata skor 2,24, kemudian berdasarkan } \\
\text { aspek pelayanan kesehatan diperoleh rata- } \\
\text { rata skor } 2,19 \text { dan yang paling rendah } \\
\text { hambatannya adalah berdasarkan status } \\
\text { fungsional dengan rata-rata skor } 2,14 \\
\text { Seluruh sub variabel memperoleh nilai } \\
\text { mean <2,5 (nilai tengah) yang berati } \\
\text { hambatannya cenderung rendah. }\end{array}$} \\
\hline
\end{tabular}

Tabel 3.

Hambatan dengan skor tertinggi pada setiap sub variabel dalam Hambatan pasien Penyakit Jantung Koroner (PJK) dalam menjalani Rehabilitasi Jantung $(\mathrm{n}=42)$

\begin{tabular}{llccc}
\hline No & \multicolumn{1}{c}{ Sub Variabel } & Hambatan & Mean & SD \\
\hline 1 & Aspek Logistik & Jarak & 2,52 & 0,63 \\
2 & Aspek Waktu & Ada kegiatan/jadwal lain & 2,29 & 0,51 \\
3 & Aspek pelayanan kesehatan & Ketidaktahuan mengenai rehabilitasi jantung & 2,38 & 0,58 \\
4 & Status fungsional & Keterbatasan fisik & 2,17 & 0,49 \\
\hline
\end{tabular}

Berdasarkan tabel 3 diperoleh bahwa hambatan jarak menjadi hambatan yang memiliki rata - rata skor tertinggi pada aspek logistik dengan hasil 2,52. Hambatan berdasarkan aspek waktu, hambatan dengan rata-rata skor tertinggi adalah dikarenakan ada kegiatan/jadwal lain yaitu sebesar 2,29. Hambatan dikarenakan ketidaktahuan para responden mengenai rehabilitasi jantung memiliki rata-rata skor tertinggi berdasarkan aspek pelayanan kesehatan dengan hasil sebesar 2,38 dan hambatan keterbatasan fisik menjadi hambatan dengan rata-rata skor tertinggi berdasarkan status fungsional pasien sebesar 2,17

Tabel 4.

Lima hambatan tertinggi dalam Hambatan pasien Penyakit Jantung Koroner (PJK) dalam menjalani Rehabilitasi Jantung $(n=42)$

\begin{tabular}{cllll}
\hline No. & Hambatan & Sub Variabel & Mean & $S D$ \\
\hline 1. & jarak & Aspek Logistik & 2,52 & 0,63 \\
2. & saya tidak mengetahui tentang rehabilitasi jantung/ & Aspek pelayanan & 2,38 & 0,58 \\
& pengetahuan mengenai rehabilitasi jantung & kesehatan & & \\
3. & masalah transportasi & Aspek logistik & 2,31 & 0,64 \\
4. & peran dalam keluarga & Aspek logistik & 2,31 & 0,64 \\
5. & ada kegiatan/jadwal lain & Aspek waktu & 2,29 & 0,51 \\
\hline
\end{tabular}

Berdasarkan tabel 4 diperoleh bahwa dari 42 responden terdapat lima hambatan dengan rata-rata skor paling tinggi yaitu hambatan jarak dari aspek logistik dengan hasil 2,52, kemudian hambatan ketidaktahuan mengenai rehabilitasi jantung dari aspek pelayanan kesehatan sebesar 2,38, masalah trasportasi sebesar 2,31 yang sama dengan nilai mean pada hambatan peran dalam keluarga dan yang terakhir adalah hambatan dikarenakan adanya kegiatan/jadwal lain sebesar 2,29. 


\section{Pembahasan}

Hambatan dalam menjalani rehabilitasi jantung dapat diketahui dengan menggunakan instrumen Cardiac Rehabilitation Barriers Scale yang membagi hambatan berdasarkan 4 aspek yaitu aspek pelayanan kesehatan, aspek logistik, aspek waktu dan status fungsional pasien. Instrumen tersebut digunakan dalam penelitian ini.

Hasil penelitian diperoleh bahwa aspek logistik (tabel 2) menjadi hambatan yang paling tinggi rata-rata skor (mean) yaitu sebesar 2,29. Aspek logistik yang memiliki skor hambatan tertinggi adalah mengenai jarak yaitu sebesar 2,52 (tabel 4.3). Hal ini sesuai dengan penelitian Lee (2011) yang mengidentifikasi beberapa alasan utama pasien tidak melaksanakan program rehabilitasi jantung yaitu hambatan fisik misalnya masalah transportasi dan jarak tempat rehabilitasi yang jauh. Hambatan jarak menjadi hambatan yang sering dirasakan pasien dikarenakan para pasien yang berobat di RSUP Dr. Hasan Sadikin Bandung merupakan pasien rujukan dari seluruh Jawa Barat sesuai dengan status Rumah Sakit Umum Pusat Dr. Hasan Sadikin (RSHS) adalah rumah sakit kelas A yang merupakan pusat rujukan provinsi Jawa Barat (www.rshs.or.id).Solusi untuk mengatasi masalah jarak ini adalah dengan menerapkan rehabilitasi jantung di setting rumah (home based cardiac rehabilitation).

Rehabilitasi jantung di rumah ini pun telah meningkatkan persentase kehadiran pada setiap sesinya yaitu $98 \%$ untuk yaang melakukan di rumah dan $81 \%$ untuk yang melakukan di rumah sakit sesuai dengan penelitian Daskapan et al., 2005. Saat ini, di Indonesia pelayanan rehabilitasi jantung masih dilakukan di rumah sakit terutama di rumah sakit besar seperti RSHS. Penelitian-penelitian di luar negeri telah banyak meneliti mengenai keefektifan dari program rehabilitasi jantung di rumah ini. Poortaghi et al., (2013) memperoleh hasil bahwa ketika seseorang pasien melakukan rehabilitasi jantung di rumah akan memberikan efek positif terhadap self efikasi pasien dan sangat direkomendasikan untuk para pasien penyakit jantung. Penerapan rehabilitasi jantung dengan setting rumah di Indonesia sangat dipengaruhi oleh tenaga medis yang memiliki keahlian dalam melakukan rehabilitasi jantung salah satunya dokter spesialis jantung. Tenaga medis yang memilki keahlian tersebut masih sangat sedikit sehingga ini akan membuat program ini tidak akan efektif. Jika tenaga medis yang memiliki kehalian tersebut sudah banyak maka yang dilakukan adalah melakukan pemantauan yang ekstra dari tenaga medis mengenai pelaksanaan rehabilitasi jantungdikarenakan hambatan yang lain yaitu berhubungan dengan pengetahuan mengenai rehabilitasi jantung yang masih rendah sehingga harus mempertimbangkan karakteristik responden. Kemudian solusi untuk mengatasi kurangnya keahlian tenaga medis mengenai rehabilitasi jantung adalah dengan meningkatkan kemandirian pasien untuk dapat melakukan rehabilitasi jantung sendiri di rumah dengan sebelumnya diberikan pengarahan dan panduan khusus pelaksanaan rehabilitasi jantung di rumah. Latihan yang bisa dilakukan di rumah antara lain berjalan, bersepeda, permainan rekreasi seperti badminton dan tenis meja (SIGN,2002). Penelitian Wu (2006) melakukan aktivitas fisik pada saat rehabilitasi jantung di rumah adalah dengan berjalan cepat atau joggingselama 30-60 menit aktivitas inti ditambah 10 menit pemanasan dan 10 menit pendinginan. Intensitas atau kecepatannya adalah 60-85 \% dari denyut nadi maksimal dari setiap pasien. Selain itu, Machionni (2003) melakukan aktivitas fisiknya dengan bersepeda sebanyak satu hari sekali dengan intensitasnya adalah 70$85 \%$ dari denyut nadi maksimal. Jika denyut nadi ketika melakukan aktivitas fisik sudah mencapai sampai batasan tersebut maka pasien harus istrirahat terlebih dahulu. Oleh karena itu, sangat 
diperlukan pendidikan kesehatan terutama pemberian informasi mengenai cara menghitung denyut nadi yang benar saat pasien masih berada pada ruang perawatan atau pada fase I.

Nilai rata-rata skor hambatan kedua tertinggi setelah hambatan berdasarkan aspek logistik adalah hambatan berdasarkan aspek waktu yaitu 2,24 (tabel 2). Hambatan dalam aspek waktu meliputi hambatan dikarenakan sudah ada jadwal lain, bekerja dan keterbatasan waktu. Pelaksanaan rehabilitasi jantung di RSHS dilakukan sebanyak 12 kali pertemuan dengan 2 kali pertemuan dalam 1 minggu dari hari Senin-Jumat. Hambatan dalam aspek waktu yang mendapatkan nilai ratarata tertinggi adalah dikarenakan sudah ada kegiatan / jadwal lain yaitu sebesar 2,29 (tabel 3). Hal ini dikarenakan banyak pasien yang mengeluh jadwal pelaksanaan rehabilitasi jantung itu tidak dalam 2 hari berurutan misalkan hari senin dan selasa tetapi yang terjadi jadwalnya adalah hari senin dan kamis. Hal ini membuat pasien banyak yang keberatan dikarenakan sudah ada kegiatan/jadwal lain. Tetapi, pada dasarnya tim pelayanan rehabilitasi jantung memperbolehkan jika ada pasien yang tidak dapat hadir sesuai jadwal. Namun waktu pelaksanaan rehabilitasi jantung tetap tidak boleh dilakukan dalam dua hari berurutan. Hal ini dikarenakan untuk menjaga kestabilan fungsi jantung yang masih harus dipantau serta agar tidak memaksakan jantung untuk bekerja terlalu berat. Banyak aktivitas fisik yang cukup berat ketika melakukan rehabilitasi jantung seperti streching, biycle ergometer, endurance training dan treadmill (SIGN,2002).

Selain itu, waktu menjadi salah satu hambatan sesuai pula dengan enelitian Brual et al. (2007) yang mendapatkan bahwa waktu mengemudi rata-rata pasien menuju tempat rehabilitasi jantung di Ontario Canada ini sekitar 60-80 menit. Jika dihubungkan dengan hambatan jarak pada aspek sebelumnya maka kedua hal ini sangat berhubungan, jarak rata-rata responden $<25 \mathrm{~km}$ tetapi ada sekitar 33,3 $\%$ responden yang memiliki jarak $>100 \mathrm{~km}$ dan jika dikonversikan ke waktu itu menghabiskan \pm 4 jam perjalanan. Waktu ini pun akan sangat dipengaruhi pula oleh karakteristik geografis wilayah Bandung yang sering macet, angkutan umum yang belum banyak dan kondisi jalan yang masih banyak dalam perbaikan. Hal terssebut dapat mmbuat waktu yang lebih lama menuju tempat rehabilitasi jantung. Maka dari itu, untuk mengatasi hambatan berdasarkan aspek waktu adalah peran perawat sebagai fasilitator dalam tim rehabilitasi dapat membuat jadwal yang sesuai dengan keinginan pasien dan pihak pelayanan kesehatan atau tim rehabilitasi jantung (Olive,2012) ataupun menerapkan rehabilitasi jantung di rumah untuk mengefektifkan waktu dan tugas perawat sebagai tenaga medis yang memantau pelaksanaan rehabilitasi jantung di rumah (Ades et al.,2000)

Aspek pelayanan kesehatan merupakan aspek selanjutnya yang menjadi hambatan dalam menjalani rehabilitasi jantung. Hambatan dalam aspek pelayanan kesehatan yang paling tinggi rata-rata skornya adalah dikarenakan tidak mengetahui rehabilitasi jantung (tabel 3). Hal ini terjadi dikarenakan responden dalam penelitian ini kebanyakan adalah pasien dengan riwayat pengobatan hanya medikasi saja dengan tidak pernah mengikuti rehabilitasi jantung (tabel 1). Hambatan mengenai pengetahuan akan rehabilitasi jantung ini sangat dipengaruhi oleh tenaga medis. Clark (2012) menyebutkan bahwa salah satu peran dari tenaga medis adalah pemberian pengetahuan mengenai rehabilitasi jantung sehingga hambatan pengetahuan sangat berkaitan dengan peran tenaga medis. Saat ini, pemberian pengetahuan mengenai program rehabilitasi jantung saat ini dilakukan hanya ketika pasien akan diindikasikan melakukan tindakan revaskularisasi jantung seperti PCI dan CABG . Hal ini sangat kurang efektif sebab pengetahuan sejak dini sangat 
diperlukan untuk mengatasi ketidakpatuhan dalam menjalani program rehabilitasi jantung terutama mengenai manfaat program. Oleh karena itu, maka pembuatan leaflet yang berisi seluruh informasi mengenai rehabilitasi jantung dapat menjadi salah satu solusi untuk meningkatkan pengetahuan serta berkoordinasi dengan dokter untuk lebih dapat meningkatkan kembali pemberian informasi mengenai rehabilitasi jantung.

Status fungsional pasien menjadi salah satu hambatan dalam menjalani rehabilitasi jantung. Status fungsional adalah status kesehatan yang berhubungan dengan kinerja dan kemandirian pasien serta kemampuan untuk berfungsi dengan baik dalam kehidupan sehari-hari (Sances, Ballesteros \& Arnold, 2011).. Hambatan dalam status fungsional yang rata-rata skornya tertinggi adalah dikarenakan keterbatasan fisik atau merasa tidak mempunyai tenaga (tabel 3).

Hal ini terjadi dikarenakan pasien yang mengalami PJK itu terjadi karena faktor resiko penyakit lainnya seperti hipertensi, hiperlipidemia, diabetes melitus (Price \& Wilson, 2006). Faktor resiko tersebut dapat memperparah kondisi pasien PJK terutama saat pasien tidak melakukan rehablitasi jantung. Salah satu hambatan berdasarkan status fungsional pasien adalah karena terhambat oleh masalah kesehatan lain yang terjadi pada pasien seperti hipertensi. Masalah kesehatan lain pun menjadi hambatan sesuai dengan penelitian Suaya et al.(2007) yang mendapatkan hasil penurunan kehadiran dalam menjalani rehabilitasi jantung dikarenakan penyakit penyerta dari pasien PJK tersebut.

Selain keterbatasan fisik, status fungsional lain yang menjadi hambatan adalah umur . Karakterisitik responden dalam penelitian ini paling banyak berada pada usia 56-65 tahun dan > 65 tahun . Hal ini sesuai dengan penelitian Wit et.al umur pasien yang banyak mengikuti rehabilitasi jantung adalah lebih dari 65 tahun . Hal ini terjadi karena penyaki PJK merupaan penyakit kronis yang sering diderita ketika berusia 56-65 tahun. Oleh karena itu, hambatan berdasarkan status fungsional pasien sangat berkaitan dengan kondisi kesehatan pasien. Oleh karena itu, untuk mengatasi hambatan dikarenakan status fungsional pasien maka peran perawat yang harus dapat mengkaji faktor resiko dari penyakit lainnya pada pasien yang dapat mengganggu status fungsional pasien terutama dalam melakukan rehabilitasi jantung (Olive,2012)

Hambatan-hambatan yang terjadi ini sangat mempengaruhi dalam kedatangan atau kepatuhan pasien PJK menjalani rehabilitasi jantung. Dalam tabel 1 pun diperoleh data bahawa responden yang rutin mengikuti hanya ada sebanyak 16 responden dan kadang-kadang hanya 2 responden dari total 42 responden. Saat seseorang rutin menjalani rehabilitasi jantung mereka akan mengungkapkan bahwa tidak ada hambatan yang berarti dalam menjalani rehabilitasi jantung. Namun, jika pasien mengungkapkan kadang-kadang menjalaninya maka ada salah satu hambatan yang terjadi dan ketika mereka tidak pernah melakukan alasan yang paling banyak diungkapkan adalah ketidaktahuan program rehabilitasi jantung dan tidak direkomendasikan oleh dokter untuk mengikutinya. Hal ini sesuai dengan teori HBM mengenai hambatan bahwa ketika seseoraang merasakan manfaat dari suatu perilaku kesehatan itu lebih besar dibandingkan hambatannya maka akan terjadi perubahan perilaku kesehatan (Glanz,2008). Ketika seseorang rutin menjalani rehabillitasi jantung dan mengungkapkan tidak ada hambatan yang berarti maka orang tersebut. telah melakukan perubahan perilaku kesehatan ke arah yang lebih baik. Berbagai hambatan yang diperoleh dalam penelitian dapat menjadi gambaran hambatan terjadi pada pasien PJK dalam menjalani rehabilitasi jantung. 


\section{Simpulan dan Saran}

Barriers atau hambatan dalam menjalani rehabilitasi jantung dengan ratarata skor tertinggi adalah aspek logistik dengan nilai mean. 2,29, selanjutnya aspek waktudengan nilai mean 2,24, aspek pelayanan kesehatan dengan nilai mean 2,19 dan yang terendah adalah berdasarkan status fungsional pasien degan nilai mean 2,14

Hasil penelitian menunjukkan bahwa hambatan berdasarkan aspek logistik yaitu jarak adalah hambatan yang sering terjadi pada pasien PJK dalam menjalani rehabilitasi jantung. Maka dari itu, peneliti menyarankan untuk dapat menerapkan rehabilitasi jantung di setting rumah (home based cardiac rehabilitation) yang disesuaikan dengan karakteristik pasien salah satunya pengetahuan jika tenaga medis yang memiiliki keahlian dalam rehabilitasi jantung cukup banyak, jika tidak maka peneliti menyarankan untuk meningkatkan kemandirian pasin melakukan rehabilitasi jantung di rumah dengan cara berjalan cepat atau jogging dengan intensitas 60-85 \% dari denyut nadi maksimal selama $30-60$ menit dan bersepeda sebanyak satu hari sekali dengan intensitasnya adalah 70-85\% dari denyut nadi maksimal Hambatan kedua tertinggi adalah hambatan dikarenakan pasien tidak mengetahui program rehabilitasi jantung. Maka dari itu, pembuatan leaflet yang berisi seluruh informasi mengenai rehabilitasi jantung. Bagi peneliti selanjutnya disarankan untuk dapat meneliti gambaran penerapan rehabilitasi jantung di setting rumah (home based cardiac rehabilitation) yang disesuaikan dengan karakteristik pasien.

\section{Daftar Pustaka}

Ades, P. A., Pashkow, F. K., Fletcher, G., Pina, I. L., Zohman, L. R., \& Nestor, J. R. (2000). A Controlled Trial of Cardiac Rehabilitation in the Home Setting Using Electrocardiograhic and Voice Transtelephonic Monitoring. American Heart Journal.
AHA. (2015). What is Cardiac Rehabilitation. Dipetik Juni 15, 2016, dari American Heart Association: http://www.heart.org/HEARTORG/C onditions/More/CardiacRehab/Whatis-Cardiac-

Rehabilitation_UCM_307049_Articl e.jsp\#.V2LOCtJ97IU

Association, A. H. (2013). Putting More Patients on the Road to Recovery. Dipetik 01 01, 2016, dari www.heart.org/policyfactssheets

Brual, J., Witte, S. G., Suskin, N., Stewart, D. E., Macpherson, A., \& Grace, S. L. (2010). Drive time to cardiac rehabilitation: at what point does it affect utilization? International Journal of Health Geographics.

Clark, A., King-Shier, K. M., Thompson, D. R., \& al, e. (2012). A qualitative systematic review of influences on attendance at cardiac rehabilitation program after referral. American Heart Journal, 835-845.

Daskapan, H., H, A., Caglar, N., N, T., \& Ataman, S. (2005). Comparison of supervised exercise training and home based exercise training in chronic heart failure. Saudi Med Journal, 26:842-7.

Depkes RI. (2006). Ditjen Bina Kefarmasian dan Alat Kesehatan Departemen Kesehatan Republik Inndonesia. Dipetik Desember 9, 2014, dari Pharmaceutical Care untuk Pasien Penyakit Jantung Koroner : Fokus Sindrom Koroner Akut.: http://binfar.depkes.go.id/download/S INDROM_KORONER_AKUT.pdf

Depkes, R. (2009). Pengertian Pelayanan Kesehatan. Diambil kembali dari www.depkes.org.id

Dominic, S., Janita, P., \& Anne, M. (2005). Acute Coronary Syndrome : 
Cardiac Rehabilitation programmes and quality of life. Journal of Advanced Nursing, 591-599.

Dunlay SM, et al., (2009). Barriers to participation in cardiac rehabilitation. American Heart Journal, 852-859.

Gielen S, B. S., \& Hambrecht. (2004). Recommended framework for cardiac rehabilitation:Cardiac Rehabilitation after Myocardial infarction. The Royal College of Nursing.

Glanz, K., Rimer, B. K., \& Vismanath, K. (2008). Health behavior and health education : theory, research, and practice fourth edition. San Francisco: Jossey-Bass.

Grace, S. 1., Shanmugaseragaram, S., Gagliese, L., Oh, P., Stewart, D. E., bRISTER, s. j., et al. (2011). Psychometric validation of the Cardiac Rehabilitation Barriers Scale. Clinical Rehabilitation, 152164.

Hastuti, F. M. (2014). Pengaruh Program Rehabilitasi Jantung Fase I Terhadap Kualitas Hidup Pasien Infarka Miokard Akut Tanpa Referfusi di RSUD Dr. Soedarso Pontianak Kalimantan Barat. Bandung: Tesis Fakultas Keperawatan Unpad.

Mair, V., Breda, A. P., Nunes, M. E., \& Matos, L. D. (2013). Evaluating compliance to A Cardiac Rehabilitation program in a Private General Hospital. einstein, 278-284.

Majid, A. (2007). Penyakit Jantung Koroner : Patofisiologi, Pencegahan dan Pengobatan Terkini.

Mampuya, W. R. (2012). Cardiac Rehabilitation Past, Present and Future : An Overview.
Cardiovascular Diagnosis \& Therapy, Vol 2 No 1.

Marchionni, N., Fattirolli, F., Fumagalli, S., Oldridge, N., Del Lungo, F., \& Morosi, L. (2003). Improved exercise tolerance and quality of life with cardiac rehabilitation of older patients after myocardial infarction:results of a randomized, controlled trial. Circulation, 107:2201-6.

Marita, I., \& Tiksnadi, B. (2015). Cardiac Rehabilitation Use Among Patients with Coronary Heart Disease on July-December 2015 in Dr. Hasan Sadikin General Hospital Bandung. Bandung: Fakultas Kedokteran Unpad.

Massimo Francesco, et al,. (2010). Seconadary prevention through cardiac rehabilitation: from knowledge to implemention. A position paper from the Cardiac Rehabilitation Section of the European Association of Cardiovascular Prevention and Rehabilitation. European Journal of Cardiovascular Prevention and Rehabilitation, 1-17.

Nurlaeci. (2015). Latihan Progresif Fase I Rehabilitasi Jantung terhadap Tekanan Darah dan Denyut Nadi pada Pasien Sindrom Koroner AKUT. Bandung: Tesis Fakultas Keperawatan Unpad.

O'Connell, S. (2014). Barriers to attending cardiac rehabilitation. Nursing Time, $15-17$.

Olive. (2012). Cardiac Rehab-Alive after Thirty five 2012-2015. Dipetik February 2015, dari http://www.aliveafter35.com

Poortaghi, S., Baghernia, A., Golzari, S. E., Safayian, A., \& Atri, S. B. (2013). 
The effect of home-based cardiac rehabilitation program on self efficacy of patients referred to cardiac rehabilitation center. $B M C$ research notes.

Potter, S., \& Wilson, L. (2006). Patofisiologi Praktik dan konsep penyakit Edisi 4 Alih Bahasa Dr. Peter Anugerah. Jakarta: EGC.

Radi, B., Joesoef, A. H., \& Kusmana, D. (2009). Rehabilitasi Kardiovaskular Di Indonesia. Jurnal kardiologi Indonesia, 43-45.

Riskesdas. (2013). Riset Kesehatan Dasar. Dipetik November 04, 2015, dari Badan Litbang Kesehatan Kementrian Kesehatan.
RSHS, Humas. (2013). Profil RSHS. Dipetik Mei 18, 2016, dari http://web.rshs.or.id/

SIGN. (2002). Cardiac Rehabilitation : A National Clinical Guideline. Scotland: Scottish Intercollegiate Guidelines Network.

Witt, B. J., Thomas, R., \& Roger, V. (2005). Cardiac rehabilitation after myocardial infarction : a review to understand barriers to participation and potensial solutions. Europa Medicophysica, Vol 41, 27-34.

Wu, S., Lin, Y., Chen, C., \& Tsai, S. (2006). Cardiac rehabilitation versus home exercise after coronary artery bypass graft surgery: a comparison of heart rate recovery. Am J Phys Med Rehabil, 711-7. 